\title{
Social Capital and Loan Repayment Capacity of Agripreneurial Groups' in Abia State, Nigeria
}

\author{
Chidinma Rosemary Okezıe a, Ifeanyi Moses Kanu b, Cynthia Chisom Iwu c, \\ aMichael Okpara University of Agriculture, Nigeria, rosynma2003@gmail.com, https://orcid.org/0000-0003-0430-1954 \\ b Michael Okpara University of Agriculture, Nigeria, ifym.skolarz@gmail.com, https://orcid.org/0000-0002-5766-193X \\ c Michael Okpara University of Agriculture,Nigeria, cynthia.chi1oo1@gmail.com, https://orcid.org/0000-0003-2272-7924
}

\section{ARTICLE INFO}

\section{Research Article}

2021, Vol. 3(3), 117-132

e-ISSN 2667-5927

Article History:

Received: 24.05.2021

Revised: 31.05 .2021

Accepted: 05.06.2021

Available Online: 25.07.2021

JEL Code: Q12, Q14, H81

Keywords: agripreneurs, social capital, loan repayment, farmers groups, abia state nigeria
Social Capital and Loan Repayment Capacity of Agripreneurial Groups' in Abia State, Nigeria

Abstract

Entrepreneurship is the ability to take significant amount of risk while managing and organizing a new or existing business enterprise with the sole motive of making profits. Agricultural entrepreneurship, also known as agripreneurship is the ability of farmers or farm firms to take substantial risks while producing, managing, directing and marketing their agricultural produce. Agripreneurs are the agricultural entrepreneurs. Selected social capital variables such as years of membership in social groups/organizations, number of meeting attendance, cash and labour contributions of members, etc., were incorporated into the research to determine the agripreneurs' loan repayment capacity in Abia State, Nigeria. A multi-stage purposive sampling technique was employed to select the respondents. Greater percentage of the agripreneurs were male. Mainstream of them were in their active and productive age, hence could form groups for easy access to credit or loans in their respective enterprises. The agripreneurial groups' sourced their loans from money lenders, ROSCA (Rotating Savings and Credit Association), family and friends/relatives. Others sources were through microfinance banks, commercial banks, self-help groups, cooperative societies and savings collectors/mobile bankers. Majority of the agripreneurs were regarded as good credit risk. The major factors affecting the agripreneurial loan repayment capacity was trust, assets, interest rate and the loan duration. Agripreneurs should be encouraged to participate more actively in group activities, not just for what they can benefit but for what they can give; as effective participation accelerates access to pooled productive resources.

To cite this document: Okezıe, C.R. \& Kanu, I. M. \& Iwu, C. C.( 2021). Social Capital and Loan Repayment Capacity of Agripreneurial Groups' in Abia State, Nigeria. BILTURK, The Journal of Economics and Related Studies, 3(3), 117132. doi: $10.47103 /$ bilturk. 941862 . 
Okezıe, C.R. \& Kanu, I. M. \& Iwu, C. C.( 2021). Social Capital and Loan Repayment Capacity of Agripreneurial Groups' in Abia State, Nigeria. BILTURK, The Journal of Economics and Related Studies, 3(3), 117-132. doi: 10.47103/bilturk.941862.

\section{Introduction}

Nigeria's agricultural policy is targeting food security and import substitution to lessen the massive food import and conserve foreign exchange (Uche and Familusi, 2018). This can be achieved if we run agriculture as a business and encourage private-sector led engagements as the key objective driver. This commercialization orientation will involve the application of technologies, development of input supply chains, market linkages and financial services that engages the farmers individually as well as within their groups (Ado, 2017). These are critical to job creation, economic diversity and sustainable economic growth. The addition of business orientation into agriculture births agribusiness, while the incorporation of entrepreneurial principles into agribusiness establishes agripreneurship (Uche and Familusi, 2018).

Agricultural lending involves fostering credit facilities in cash and in kind to farmers, inputs suppliers, processors and agricultural marketers'. In Nigeria, agricultural credit has long been identified as a major input in the development of the agricultural sector. Over the years, credit offering institutions have found it comfortable and less riskier in granting loan facilities to groups as opposed to individual farmers or agripreneurs because they envisaged that members of a group would hold each other in check to prevent mismanagement of funds (Oladeebo and Oladeebo, 2008).

Consequently, considering the social connections which social capital provides to help people get along with each other and act more effectively than they could as isolated individuals (Okezie et al., 2020), several social capital variables such as years of membership in diverse social groups/organizations, number of meeting attendance, cash contribution of members, labour contribution of members, etc., were incorporated into the research to determine agripreneurs' loan procurement, disbursement and repayment capacity in Abia State, Nigeria.

Social capital, either through its function in social control or accumulation of mutual benefits is critical for successful operation of group lending. For instance, social links among borrowers may increase their ability to participate in credit transactions that involve some uncertainty about compliance. Specifically, social capital can lead to a better flow of information between lenders and borrowers and hence less adverse selection and moral hazard in the credit market. Social capital also potentially expands the range of enforcement mechanisms for loan defaulters in situations in which recourse to legal system is costly or impossible. Typically, loan is given to 'a group' without tangible collateral but with reliance on guaranteed repayment through group approval and joint liability among group members. The principle of joint liability stipulates that all group members are treated as being in default if any one member of the group does not repay her or his loan. The enforceable trust is the source of social capital and is appropriable by both lenders and borrowers. For the borrowers, it facilitates access to credit and for lenders, it 
yields approval, expedites transactions and insures against risk of default (Olomola, 2008).

The study examined social capital and loan repayment capacity of agripreneurial groups' in Abia State, Nigeria.

\section{Research Methodology}

\subsection{Study Area}

The research was carried out in Aba North Local Government Area (LGA) of Abia State, Nigeria. Aba North LGA is one of the 17 Local Governments Areas of Abia State. Its headquarter lies in the town of Eziama Urata. Aba North is strategically located in the southern part of Abia State. It shares boundaries with other Local Governments like Ossioma, Aba South, Isiala Ngwa South, Ugwunaagbo and Obingwa Local government Areas of Abia State. The LGA is a commercial center filled with lots of businesses/firms, agencies, social institutions and governmental and non-governmental organizations. There are lots of financial institutions (formal and informal) spread all over the LGA. The citizens were predominantly Igbo tribe.

\subsection{Sample Selection and Sampling Procedure}

A multi-stage purposive sampling technique was employed to select the sampled agripreneurs. In the first stage, Aba North LGA was purposively selected because of the presence of numerous microfinance and agripreneurial groups. In the second stage, 40 agripreneurial groups were randomly selected from over a 1,000 agripreneurial groups in Aba North LGA. In the third stage, two (2) agripreneurs were randomly selected from each of the groups respectively, making it a total of 80 respondents chosen for the study. A well-structured questionnaire was administered to the randomly sampled respondents.

\subsection{Analytical Techniques}

Descriptive and inferential statistics were employed to analyze the data obtained from the study. The effects of social capital on loan repayment among the agripreneurial groups' was analyzed with the application of multiple regression model.

The model was specified as:

$\mathrm{Y}=f\left(\mathrm{X}_{1}, \mathrm{X}_{2}, \mathrm{X}_{3}, \ldots \ldots . . . . \mathrm{X}_{12}, \mu\right)$

$Y=\beta_{0}+\beta_{1} X_{1}+\beta_{2} X_{2}+\beta_{3} X_{3}+\ldots \ldots \ldots+\beta_{12} X_{12}+\mu$

$\mathrm{Y}=$ Loan repayment capacity of agripreneurial groups' in Naira ( $\mathrm{A})$.

The explanatory variables specified in the model included: 
Okezıe, C.R. \& Kanu, I. M. \& Iwu, C. C.( 2021). Social Capital and Loan Repayment Capacity of Agripreneurial Groups' in Abia State, Nigeria. BILTURK, The Journal of Economics and Related Studies, 3(3), 117-132. doi: 10.47103/bilturk.941862.

\section{(A) Group Characteristics}

$\mathrm{X}_{1}=$ Age of Group head/leader (in Years)

$\mathrm{X}_{2}=$ Sex of Group's leader (Male $=1$, Female $=0$ )

$X_{3}=$ Years of education of Group leaders

$\mathrm{X}_{4}=$ Interest rate charge on loan (\%)

$\mathrm{X}_{5}=$ Loan duration (months)

$\mathrm{X}_{6}=$ Trust (Members in Group can be Trusted $=1$, Otherwise $=0$ ).

\section{(B) Social Capital Characteristics}

$\mathrm{X}_{7}=$ Density of Membership (\%)

$\mathrm{X}_{8}=$ Cash Contribution of agripreneurs in their respective Groups (\%)

$\mathrm{X}_{9}=$ Labour Contribution of agripreneurs in their respective Groups (\%)

$\mathrm{X}_{10}=$ Decision Making index of agripreneurs in their respective Groups (\%)

$\mathrm{X}_{11}=$ Meeting Attendance of agripreneurs in their respective Groups (\%)

$\mathrm{X}_{12}=$ Heterogeneity Index of agripreneurs in their respective Groups (\%)

The density of membership is a complete inventory of all associations/groups in which the agripreneurs belongs. The density of membership index was captured by the summation of the total number of associations to which each agripreneurs belongs. Cash contribution index was achieved by taking records of payment of membership dues and other contributions by the agripreneurs in their various groups. Meeting attendance index is the number of times the agripreneurs belonging to their various groups met over a period of time. It is simply the summation of attendances of the agripreneurs at meetings.

$\boldsymbol{\beta}_{0}=$ regression intercept; which measured the effects of the dependent variable, assuming other exogenous variables were held constants.

$\boldsymbol{\beta}_{1-12}=$ regression slopes/coefficients; which captures the effects of the dependent variable on the specified explanatory variables (X's).

$\mu=$ Stochastic error term.

To analyze the factors affecting loan repayment among the agripreneurial groups in Aba North LGA, the project makes use of the logistic regression model. Logistic regression is based on binomial probability theory. It is a mathematical modeling approach used in describing relationship of several exogenous variables to a dichotomous endogenous variable or a limited dependent variable (Agbemava et al., 2016). The logit function is employed because the dependent variable default is dichotomous, whereas the proposed covariates were mixture of continuous and 
categorical random variables. Thus the model was chosen over others due to the data structure and purpose. The logit model is a derivative of the odds function. The odd of a function is the ratio of the probability of success to that of failure. Thus

Odds $(Y=1)=\frac{P(Y=1 / X=x)}{P(Y=0 / X=x)}$

Where $\operatorname{Odds}(Y=1)$ is the odds of loan default; $P(Y=1)$ is the probability that loan default occurs given a set of explanatory variables and $(Y=0)$ is the probability of non-default given set of explanatory variables. If the odds of loan default $>1$ it implies there are higher probability of default compared to that of non-default. A value less than one indicate a higher probability of non-default than that of default.

The probability distribution of loan defaults in a given loan portfolio size for any given values of explanatory variables is binomial. Thus, the probability that the number of default of a given portfolio size $\mathbf{n}$ is exactly equal to size $x$, is given by ( $X$ $=x)=\frac{n !}{x !(n-x) !} p x q n-x$.

Where $q=P y(0)=$ probability of non-default. This means that given a portfolio size $n$ and probability of default $P(Y=1)$ from a financial group or institution, one can use the theorem to perform risk control analysis.

The variables are defined as:

$\mathrm{Y}=$ Repayment capacity (Ioan repaid on time $=1$, not repaid on time $=0$ )

$\mathrm{X}_{1}=$ Income per group ( $\mathrm{N} /$ month)

$X_{2}=$ Trust (Members in Group can be Trusted $=1$, Otherwise $=0$ )

$\mathrm{X}_{3}=$ Off-farm Employment of group members (Yes $=1, \mathrm{No}=0$ )

$X_{4}=$ Asset (Total value of Assets in $N$ per group)

$X_{5}=$ Interest rate charge on loan (\% / group member)

$X_{6}=$ Loan Duration (number of months)

$X_{7}=$ Political party affiliation (Member of Political party $=1$, Otherwise $=0$ ). 
Okezıe, C.R. \& Kanu, I. M. \& Iwu, C. C.( 2021). Social Capital and Loan Repayment Capacity of Agripreneurial Groups' in Abia State, Nigeria. BILTURK, The Journal of Economics and Related Studies, 3(3), 117-132. doi: 10.47103/bilturk.941862.

\section{Socio - Demographic Variables of Agripreneurs in Aba North, Abia State}

Recorded in Table 1 are the minimum, maximum, mean, frequency and percentage distribution of the agripreneurs' socio economic variables.

Table 1: Summary of Socio Economic Profile of Agripreneurs' in Aba North

\begin{tabular}{|c|c|c|c|}
\hline & Frequency & & $\begin{array}{c}\text { Percentage } \\
(\%)\end{array}$ \\
\hline \multirow[t]{2}{*}{ Gender } & Male & 52 & 65.00 \\
\hline & Female & 28 & 35.00 \\
\hline Total & & 80 & 100 \\
\hline Age (Years) & $20-30$ & 23 & 28.75 \\
\hline Minimum (20) & $31-40$ & 31 & 38.75 \\
\hline Maximum (60) & $41-50$ & 19 & 23.75 \\
\hline Mean $\quad$ (38.94) & $51-60$ & 7 & 8.75 \\
\hline Total & & 80 & 100 \\
\hline \multirow[t]{4}{*}{ Marital Status } & Single & 41 & 51.25 \\
\hline & Married & 30 & 37.50 \\
\hline & Divorced & 6 & 7.50 \\
\hline & Widowed & 3 & 3.75 \\
\hline Total & & 80 & 100 \\
\hline \multirow[t]{4}{*}{ Educational Level } & No Formal Education & 13 & 16.25 \\
\hline & Primary Education & 29 & 36.25 \\
\hline & Secondary Education & 32 & 40.00 \\
\hline & Tertiary & 6 & 7.50 \\
\hline Total & & 80 & 100 \\
\hline \multicolumn{4}{|l|}{ Household Size } \\
\hline Minimum (2) & $2-4$ & 31 & 38.75 \\
\hline Maximum (10) & $5-7$ & 39 & 48.75 \\
\hline Mean $\quad(6.01)$ & $8-10$ & 10 & 12.50 \\
\hline Total & & 80 & 100 \\
\hline
\end{tabular}

Source: Field Survey Data, 2018

Table 1 shows the socio economic characteristics of the agripreneurs in Aba North, Abia State. From Table 1, it was observed that $65 \%$ of the agripreneurs were male, while the other $35 \%$ were female. The result suggests that greater percentage of the respondents were male.

Age distribution of the sampled agripreneurs shows that $28.75 \%$ were within the age brackets of $20-30$ years, while $31-40$ years represents $38.75 \%$ of the sampled agripreneurs; whereas $41-50$ years and $51-60$ years represent $23.75 \%$ and $8.75 \%$ of the respondents respectively. The minimum age of the agripreneurs in the study area was 20 years; while the maximum years were 60 years. The agripreneurial groups have an average age of 38.94 (approximately 39 years). This result infers 
that mainstream of the agripreneur were in their active and productive age; hence could form groups' for easy access of credit and loan.

A total of $51.25 \%$ of the agripreneurs were single; while $37.50 \%, 7.50 \%$ and $3.75 \%$ were married, divorced and widowed respectively. The result implies that majority of the agripreneurs in the study area were single.

Educational distribution of the respondents in Table 1 reveals that $16.25 \%$ and $36.25 \%$ of the agripreneurs had no formal education and had primary school education respectively; while $40 \%$ and $7.50 \%$ had secondary school certificate of education (SSCE) and bachelor's degree respectively. The result surmises that preponderance of the sampled agripreneurs had secondary school education. This infers that the respondents were reasonably educated.

Household size of the agripreneurs depicts that about $38.75 \%$ had a family size of 2-4 members; while $48.75 \%$ had household size of 5-7 persons. Only $12.50 \%$ of the sampled agripreneurs in the study area had household size of 8-10 persons. The minimum and maximum household size was 2 and 10 persons respectively; however the average household size was 6 persons. The result infers that the household size of the respondents were quite moderate. The findings are in consonance with Yusuf (2008) who found that households in Nigeria had an average of 6.0 - 7.0 persons. Similarly, Kanu (2020) noted that the average household size for cocoa farmer's agripreneurs in Abia state was 7 persons. This result may have positive effects on the availability of family labour for the agripreneurs which could lead to increase in the level of their output/production.

Table 2 shows additional socio demographic indices for the agripreneurs in the study area. The additional socio economic variables included the agripreneurs' years of experience in their respective agripreneurial enterprises, as well as their average monthly income and credit/loan demand status. Further, these demographic variables were employed as exogenous variables in analyzing the factors affecting effects of social capital and agripreneurial group loan repayment capacity in the study area.

The average years of experience of the agripreneurs was 9.78 (approximately 10 years) with 1 year and 25 years as the minimum and maximum years of experience. Majority of the agripreneurs (40\%) had 6-10 years of agripreneurial experience in their respective enterprises. The mean income of the entrepreneurs in the study area was $\$ 51,762.50$. Additionally, a total of $76.25 \%$ of the agripreneurs noted they requested for credit/loans from their agripreneurial groups' and other financial institutions (formal and informal); while the other $23.75 \%$ specified otherwise. The results submit that greater percentage of the agripreneurs in the study area requested for credit/loans. Contrarily, Kanu and Nwaru (2020) observed that poultry agripreneurs' in Ikwuano LGA, Abia state were unwilling to request for 
Okezıe, C.R. \& Kanu, I. M. \& Iwu, C. C.( 2021). Social Capital and Loan Repayment Capacity of Agripreneurial Groups' in Abia State, Nigeria. BILTURK, The Journal of Economics and Related Studies, 3(3), 117-132. doi: 10.47103/bilturk.941862.

credit/loan, this may be because of the bureaucratic bottleneck in obtaining credit/loans from financial institutions; not counting disagreements within members of the agripreneurial groups.

Table 2: Additional Socio Economic Variables of Agripreneurs in Aba North

\begin{tabular}{lccc}
\hline \hline & & Frequency & Percentage (\%) \\
\hline \hline Years of Experience & $1-5$ & 18 & 22.50 \\
in Your Enterprise & $6-10$ & 32 & 40.00 \\
Minimum (1) & $11-15$ & 15 & 18.75 \\
Maximum (25) & $16-20$ & 9 & 11.25 \\
Mean (9.78) & $21-25$ & 6 & 7.50 \\
Total & & 80 & 100 \\
\hline \hline Income per & $7,000-17,000$ & 14 & 17.50 \\
Month (\#) & $18,000-28,000$ & 12 & 15.00 \\
& $29,000-39,000$ & 10 & 12.50 \\
Minimum (7,000) & $40,000-50,000$ & 8 & 10.00 \\
Maximum (99,000) & $51,000-60,000$ & 20 & 25.00 \\
Mean (51,762.5) & $61,000-70,000$ & 7 & 8.75 \\
& $71,000-80,000$ & 4 & 5.00 \\
(@ A369.85 to \$1.00) & $81,000-90,000$ & 2 & 2.50 \\
& $91,000-99,000$ & 3 & 3.75 \\
Total & & $\mathbf{8 0}$ & 100 \\
\hline \hline Requested Credit or & Yes & 61 & 76.25 \\
Loan? & No & 19 & 23.75 \\
Total & & $\mathbf{8 0}$ & 100 \\
& & &
\end{tabular}

Source: Field Survey Data, 2018

\section{Analysis of the Volume of Loan Repaid by Agripreneurs in Aba North, Abia State}

The demand for loans among agripreneurs in Aba North cannot be over emphasized as it enables them to establish and expand their enterprises. Table 3 is the average amount of loan repaid by the agripreneurial groups' in Aba North, Abia State, Nigeria. The group sourced their loans from money lenders, ROSCA, family and friends, microfinance banks, commercial banks, self-help group, cooperative societies and savings collectors/mobile bankers. Karlan (2006) specified that during group scheduled meetings or social gatherings, several activities occur including loan procurements and repayment, cash contribution, trainings, etc.

In the same vein, Table 3 shows that the total amount of loans requested by agripreneurs from money lenders was $\$ 450,000$; while that of ROSCA and family/friends was $\$ 350,000$ and $\# 145,500$ respectively. Loans requested from microfinance banks, commercial banks and self-help groups were 295,000 , $\# 350,000$ and $\$ 265,000$ respectively. Cooperatives and mobile bankers had loans 
Okezıe, C.R. \& Kanu, I. M. \& Iwu, C. C.( 2021). Social Capital and Loan Repayment Capacity of Agripreneurial Groups' in Abia State, Nigeria. BILTURK, The Journal of Economics and Related Studies, 3(3), 117-132. doi: 10.47103 /bilturk.941862.

request of $\$ 200,000$ and $\$ 120,000$ respectively. The total amount of loan requested by the agripreneurial groups' in Aba North was $\$ 2,235,500$.

Table 3: Average Amount of Loan Repaid by Agripreneurial Groups' in Aba North, Abia State

\begin{tabular}{|c|c|c|c|c|}
\hline $\begin{array}{l}\mathrm{S} / \\
\mathrm{N}\end{array}$ & Sources of Loan & $\begin{array}{c}\text { Loan } \\
\text { Requeste } \\
\text { d (\#) }\end{array}$ & $\begin{array}{c}\text { Loan } \\
\text { Received } \\
\text { (\#) }\end{array}$ & $\begin{array}{c}\text { Loan Re-paid } \\
\text { (\#) }\end{array}$ \\
\hline 1. & Money Lenders & 450,000 & 425,000 & 350,000 \\
\hline 2. & ROSCA & 350,000 & 350,000 & 350,000 \\
\hline 3. & Family/Friends & 145,500 & 110,000 & 80,000 \\
\hline 4. & Microfinance Banks & 295,000 & 260,000 & 210,000 \\
\hline 5. & Commercial Banks & 350,000 & 275,000 & 195,500 \\
\hline 6. & Self-help Group & 265,000 & 265,000 & 200,000 \\
\hline 7. & Cooperative Societies & 200,000 & 200,000 & 200,000 \\
\hline 8. & $\begin{array}{l}\text { Savings collectors/Mobile } \\
\text { bankers }\end{array}$ & 120,000 & 110,000 & 110,000 \\
\hline \multirow[t]{2}{*}{9.} & Others & 60,000 & 50,000 & 40,000 \\
\hline & Total & $2,235,500$ & $2,045,000$ & $1,735,500$ \\
\hline
\end{tabular}

* = Multiple responses recorded. Exchange rate @ $\$ 369.85$ to $\$ 1.00$

Source: Computed from field survey data, 2018

The volume of loan repaid by the agripreneurial groups' was also presented in Table 3 column 5; from the Table, it was observed that $\$ 350,000$ was repaid by the respondents who received $\$ 425,000$ from money lenders. A total of $\$ 350,000$ was requested and received by the agripreneurial groups' who were involved with ROSCA. ROSCA and Cooperative society were the most transparent financial institution as of the time of this research. This is because, the amount of loan requested was equaled to the amount of loans received by the borrowers. Generally, the total amount of loan received by the agripreneurial groups' was $\$ 2,045,000$ as against $\$ 1,735,500$ which was repaid. The difference in the amount of loan received and repaid was $\$ 309,500$. This result infers that the total amount of loan received by the agripreneurial groups' was not the total amount repaid.

Table 4 shows the loan repayment status of the agripreneurial groups' in the study area. The figures in parentheses represent percentage measure. Multiple responses were recorded as most of the respondents borrowed funds from two or three credit institutions. It is worthy to note that the agripreneurial groups' who repaid their loans as at when due or within one month after the due date were referred to as good credit risks. On the other hand, some agripreneurial borrowers repaid their loans with arrears, that is, payment of their loans took place within three months after the due date. Such borrowers were classified as delinquents; 
Okezıe, C.R. \& Kanu, I. M. \& Iwu, C. C.( 2021). Social Capital and Loan Repayment Capacity of Agripreneurial Groups' in Abia State, Nigeria. BILTURK, The Journal of Economics and Related Studies, 3(3), 117-132. doi: 10.47103/bilturk.941862.

while those who did not repay their loans at least 90 days after the due date were regarded as defaulters.

Table 4: Loan Repayment Status of Agripreneurial Groups' in Aba North, Abia State

\begin{tabular}{llcclc}
\hline \hline S/N & $\begin{array}{l}\text { Source of Loan } \\
\text { Borrowed }\end{array}$ & $\begin{array}{c}\text { Number of } \\
\text { Participant* }\end{array}$ & $\begin{array}{c}\text { Good Credit } \\
\text { Risks }\end{array}$ & Delinquents & Defaulters \\
\hline \hline 1. & Money Lenders & $31(38.75 \%)$ & $12(15.00 \%)$ & $16(20.00 \%)$ & $3(3.75 \%)$ \\
2. & ROSCA & $26(32.50 \%)$ & $14(17.50 \%)$ & $5(6.25 \%)$ & $7(8.75 \%)$ \\
3. & Family/Friends & $73(91.25 \%)$ & $27(33.75 \%)$ & $15(18.75 \%)$ & $31(38.75 \%)$ \\
4. & Microfinance Banks & $45(56.25 \%)$ & $14(17.50 \%)$ & $13(16.25 \%)$ & $18(22.50 \%)$ \\
5. & Commercial Banks & $38(47.50 \%)$ & $13(16.25 \%)$ & $9(11.25 \%)$ & $16(20.00 \%)$ \\
6. & Self-help Group & $33(41.25 \%)$ & $16(20.00 \%)$ & $6(7.50 \%)$ & $11(13.75 \%)$ \\
7. & Cooperative Societies & $42(52.50 \%)$ & $19(23.75 \%)$ & $14(17.50 \%)$ & $9(11.25 \%)$ \\
8. & Mobile bankers & $44(55.00 \%)$ & $24(30.00 \%)$ & $8(10.00 \%)$ & $12(15.00 \%)$ \\
9. & Others & $13(16.25 \%)$ & $6(7.50 \%)$ & $3(3.75 \%)$ & $4(5.00 \%)$ \\
& Total & & $\mathbf{1 4 5}$ & $\mathbf{8 9}$ & $\mathbf{1 1 1}$ \\
\hline \hline
\end{tabular}

* = Multiple responses recorded.

Source: Computed from field survey data, 2018

About $91.25 \%$ of the agripreneurs obtains financial assistance from family and friends; whereas $56.25 \%$ obtain their financial aid from microfinance banks; however $55 \%$ obtain their loans from mobile bankers. The loan repayment status of the agripreneurial groups' shows that on a total of 145 occasions, the agripreneurs were classified as good credit risk; i.e. they repaid their loans as at when due or within one month of their due time. On 89 and 111 occasions, the respondents were regarded as delinquents and defaulters. This result implies that majority of the agripreneurs in the study area were regarded as good credit risk.

A similar study by Abbink et al., (2006) effectively captures the idea that group lending is heavily dependent on dynamic incentives. This is because agripreneurial groups' have an incentive to repay group loans if they believe a percentage of other group members will do the same. That belief that other members will contribute in the current round is partially a function of the social capital that exists within the borrowing group, which may be a product of a borrowing group member's generalized trust in her society as a whole (according to Abbink et al., 2006).

Binary logistic regression showing the factors affecting agripreneurial groups' loan repayment was presented in Table 5. From Table 5, the coefficient of the likelihood ratio of Chi-square was 31.76, which was significant at $1 \%$ level; indicating a good fit for the estimated logistic model. The constant term ( $\beta 0)$ was negative and statistically significant at $5 \%$ level with an odd ratio of -2.05 . This implies that repayment capacity (credit/loan repaid on time) will decrease by 2.05 assuming other explanatory variables were held constant. 
Okezıe, C.R. \& Kanu, I. M. \& Iwu, C. C.( 2021). Social Capital and Loan Repayment Capacity of Agripreneurial Groups' in Abia State, Nigeria. BILTURK, The Journal of Economics and Related Studies, 3(3), 117-132. doi: 10.47103 /bilturk.941862.

Table 5: Logistic Regression showing the Factors Affecting Agripreneurial Groups' Loan Repayment Capacity in Aba North, Abia State, Nigeria

\begin{tabular}{llll}
\hline \hline Variable & Odd Ratio & $\begin{array}{l}\text { 95\% Confident } \\
\text { Interval }\end{array}$ & P-Value \\
\hline \hline$\left(X_{1}\right)$ Income per group & 1.08 & $0.22-1.56$ & 0.137 \\
$\left(X_{2}\right)$ Trust & 2.04 & $0.98-1.08$ & $0.029^{*}$ \\
$\left(X_{3}\right)$ Off-farm Employment & 0.63 & $0.91-1.12$ & 0.348 \\
$\left(X_{4}\right)$ Asset & 3.21 & $2.44-3.67$ & $0.035^{*}$ \\
$\left(X_{5}\right)$ Interest rate charge on loan & -4.05 & $2.99-3.08$ & $0.002^{* *}$ \\
$\left(X_{6}\right)$ Loan Duration & 3.94 & $0.98-1.07$ & $0.007^{* *}$ \\
$\left(X_{7}\right)$ Political party affiliation & 1.33 & $0.77-1.14$ & 0.451 \\
$\left(\beta_{0}\right)$ Constant & -2.05 & $1.47-2.03$ & $0.048^{*}$ \\
Pseudo R-square & 0.582 & & \\
Chi square & $31.76^{* * *}$ & & 0.001 \\
\hline \hline
\end{tabular}

Legend: ${ }^{* *}$ Significance at $1 \%$ level; ${ }^{*}$ Significance at $5 \%$ level.

Source: Field Survey Data, 2018.

The pseudo R2 or the measure of goodness of fit is used to judge the explanatory power of the independent variables on the endogenous variable (loan repayment capacity). The pseudo R2 denotes the percentage of variations in the dependent variable accounted for by the variations in the independent variables. Thus, the higher the pseudo R2, the more the model is able to explain the changes in the dependent variable due to changes in the independent variables. The logit model has a pseudo R2 of 0.505 , implying that $50.5 \%$ of the variation in the dependent variable (loan repayment capacity) was explained by the exogenous variables (X1$\mathrm{X7)}$. This result suggests that the explanatory variables had a significant influence on group loan repayment of the agripreneurs in the study area. The result shows that trust (X2), assets (X4), interest rate (X5) and loan duration (X6) were the significant variables influencing agripreneurial groups' loan repayment capacity in Aba North, Abia State, Nigeria.

Membership trust was significant at $5 \%$ level with a positive odds ratio of 2.04 . This implies that loan repayment will increases as the members of the group have higher level of trust within themselves. This result implies that if the membership trust is increased by 1 unit, loan repayment capacity will increase by 2.04 units.

Similarly, asset of the members in the group was positive with an odd ratio of 3.21. The result is statistically significant at $5 \%$. This infers that loan repayment will rise if the level of the agripreneurial groups' assets is increased. This shows that if the group assets were increased by 1 unit, loan repayment capacity will rise by 3.21 units. 
Okezıe, C.R. \& Kanu, I. M. \& Iwu, C. C.( 2021). Social Capital and Loan Repayment Capacity of Agripreneurial Groups' in Abia State, Nigeria. BILTURK, The Journal of Economics and Related Studies, 3(3), 117-132. doi: 10.47103/bilturk.941862.

Result from Table 5 shows that interest rate charged on loan was significant at $1 \%$ level; with a negative odds ratio of -4.05 . This implies that the loan repayment capacity of the agripreneurs will decrease as the interest charged on the borrowed loan increases. This implies that, if the interest charged on loan is increased by 1 unit, loan repayment capacity will decrease by 4.05 units. This result is in conformity to the findings of Oladeebo and Oladeebo (2008) in their study entitled "Determinants of loan repayment among small-holder farmers in Ogbomoso agricultural zone of Oyo state, Nigeria.

In the same strain, loan duration period was significant at $1 \%$ level; with a positive odd ratio of 3.94. This implies that loan repayment will increase as the loan duration rises. This suggests that if the loan duration was increased by 1 unit, loan repayment capacity of the agripreneurial groups' will rise by 3.94 units; assuming other factors not included in the logit model were held constant.

Table 6: Multiple Regression Coefficients showing the Influence of Social Capital on Agripreneurial Groups' in Aba North, Abia State, Nigeria

\begin{tabular}{lcccc}
\hline \hline Variables & Coefficient & $\begin{array}{c}\text { Standard } \\
\text { error }\end{array}$ & $\mathbf{t}-$ ratio & $\begin{array}{c}\text { p- } \\
\text { value }\end{array}$ \\
\hline \hline$\left(\beta_{0}\right)$ Constant & -5.8422 & 3.3091 & $-1.7655^{*}$ & 0.037 \\
$\left(X_{1}\right)$ Age of Group head & 2.7656 & 6.3199 & 0.4376 & 0.276 \\
$\left(X_{2}\right)$ Sex of Group head & 0.1137 & 0.1678 & 0.6775 & 0.458 \\
$\left(X_{3}\right)$ Years of Education of Group head & 3.3239 & 1.9865 & $1.6732^{*}$ & 0.048 \\
$\left(X_{4}\right)$ Interest rate charge on loan (\%) & 0.7661 & 0.7601 & 1.0078 & 0.387 \\
$\left(X_{5}\right)$ Loan Duration (months) & 2.6294 & 0.2442 & $10.7674^{* *}$ & 0.001 \\
$\left(X_{6}\right)$ Trust (Trust = 1, Otherwise $\left.\left.=0\right)\right)$ & 1.6175 & 17.5471 & 0.0921 & 0.126 \\
$\left(X_{7}\right)$ Density of Membership Index & 1.5092 & 0.8061 & $1.8722^{*}$ & 0.028 \\
$\left(X_{8}\right)$ Cash Index of Group & 1.8036 & 0.1934 & $9.3257^{* *}$ & 0.005 \\
$\left(X_{9}\right)$ Labour Contribution Index & 0.6972 & 0.6463 & 1.0787 & 0.587 \\
$\left(X_{10}\right)$ Decision Making Index & 1.5541 & 2.6868 & 0.5784 & 0.318 \\
$\left(X_{11}\right)$ Meeting Attendance Index & 0.4321 & 0.2567 & $1.6832^{*}$ & 0.027 \\
$\left(X_{12}\right) \quad$ Heterogeneity Index & 0.7128 & 0.6919 & 1.0302 & 0.767 \\
Association & & & & \\
$\mathbf{R}$ & & & & \\
$\mathbf{R}^{\mathbf{2}}$ & $\mathbf{0 . 6 4 9}$ & & & \\
F-Statistics & $\mathbf{0 . 4 2 1}$ & $\mathbf{0 . 0 0 1}$ & & \\
\hline \hline
\end{tabular}

Legend: ** Significance at 1\%, * Significance at 5\%: Source: Field Survey Data, 2018.

The multiple regression coefficients showing the influence of social capital on group loan repayment among the agripreneurial groups' in the study area was presented in Table 6. The regression model has a multiple determination (R2) value of 0.421 , implying that $42.1 \%$ of the variation in the dependent variable (agripreneurial group loan repayment capacity) was explained by the various exogenous variables (X1-X12). This suggests that the exogenous variables had a significant influence on group loan repayment capacity among the sampled agripreneurial groups' in Aba North, Abia State. The F-ratio was 28.44 and statistically significant at $1 \%$ level; 
which implies that the model has a good fit. The constant term $(\beta 0)$ was negative and statistically significant at $5 \%$ level with a coefficient of -5.8422 . This implies that the group loan repayment capacity will decrease by $\$ 584.22$ assuming other explanatory variables were held constant.

From Table 6, it was observed that five out of the twelve exogenous variables employed in the model statistically influence group loan repayment capacity among the agripreneurs in the study area. The significant variables were years of education (X3), loan duration (X5), density of membership index (X7), cash contribution index of group (X8) and meeting attendance index (X11).

Years of education was statistically significant at $5 \%$ level; with a positive coefficient of 3.3239; indicating that the group loan repayment capacity among the entrepreneurs will increases as their years of education rises. This result connotes that an increase in the educational level of the group head, will invariable increase the group loan repayment capacity by $\$ 332.39$.

The loan duration in months was positive and statistically significant at $99 \%$ level of confidence; with a coefficient of 2.6294; inferring that the agripreneurial group loan repayment capacity will increases as the loan duration increases. The result suggests that an increase in loan duration of the group will unwaveringly increase their loan repayment capacity by 262.94 .

The fundamental function attributed to social capital is the ability of people to 'group' together in order to obtain some collective benefit. The density of membership is a complete inventory of all associations/groups in which the entrepreneurs belongs. The density of membership index was captured by the summation of the total number of associations to which each agripreneurs belongs. Density of membership index of the entrepreneur was positive and statistically significant at $5 \%$ level; with a coefficient of 1.5092. This implies that a unit increase in membership index of the agripreneurs, their loan repayment capacity by \#150.92. The result suggests that, the higher the memberships index of the agripreneurs, the greater their loan repayment capacity. Olomola (2008) stated that the nature of membership in social organizations is crucial for improved performance of groups not only in terms of homogeneity but also in terms of inherent social capital which can be of great benefit to both lenders and borrowers.

Cash contribution index was achieved by taking records of payment of membership dues and other contributions by the agripreneurs in their various groups. Cash contribution index of the entrepreneur was positive and statistically significant at $1 \%$ level; with a coefficient of 1.8036 . This implies that a unit increase in cash contributed by the various entrepreneurs' in their groups will result in 180.36 rise in their loan repayment capacity. The result suggests that the higher the cash 
Okezıe, C.R. \& Kanu, I. M. \& Iwu, C. C.( 2021). Social Capital and Loan Repayment Capacity of Agripreneurial Groups' in Abia State, Nigeria. BILTURK, The Journal of Economics and Related Studies, 3(3), 117-132. doi: 10.47103/bilturk.941862.

contributions index of the agripreneurs in their respective groups/association, the higher their loan repayment capacity.

Meeting attendance significantly affected the group loan repayment capacity in the study area. Meeting attendance index is the number of times the agripreneurs belonging to their various groups met over a period of time. It is simply the summation of attendances of the entrepreneurs at meetings. The meeting attendance index of the group was positive and statistically significant at $5 \%$ level with a coefficient of 0.4321 . This implies that a unit increase in meeting attendance among the entrepreneurs in their groups will increase their loan repayment capacity by 43.21 . This result infers that the higher the meeting attendance of the entrepreneurs, the greater their loan repayment capacity.

Ajani and Tijani (2009) and Lawal et al., (2009) observed that factors such as heterogeneity, meeting attendance, cash contributions and decision making indices as the social capital factors that positively influenced the probability of farmers' access to credit from financial institutions in Nigeria. Correspondingly, Armendariz and Morduch (2005) noted that the success of group lending approach in accessing credit/loan and lowering default rates relies heavily on social capital.

\section{Conclusion and Recommendation:}

Greater percentage of the agripreneurs were male. Mainstream of them are in their active and productive age hence could form groups for easy access to credit and loan in their respective enterprises. The agripreneurial group' sourced their loans from money lenders, ROSCA (Rotating Savings and Credit Association), family and friends, microfinance banks, commercial banks, self-help group, cooperative societies and savings collectors/mobile bankers. The total amount of loan received by the agripreneurs was not the total amount repaid by the group agripreneurs. Majority of the agripreneurs in the study area were regarded as good credit risk. The major factors affecting the agripreneurial group loan repayment capacity was trust, assets, interest rate charged on loans and the loan duration. Agripreneurs should be encouraged to participate more actively in group activities, not just for what they can get but for what they can give; as effective participation in association's decision making facilitates efficient access to productive resources like credit, labour among other resources. 
Okezıe, C.R. \& Kanu, I. M. \& Iwu, C. C.( 2021). Social Capital and Loan Repayment Capacity of Agripreneurial Groups' in Abia State, Nigeria. BILTURK, The Journal of Economics and Related Studies, 3(3), 117-132. doi: 10.47103/bilturk.941862.

\section{References}

Abbink, K., Irlenbusch, B. \& Renner, E. (2006). Group size and social ties in microfinance institutions, Economic Inquiry, vol. 44(4), pp. 614-28.

Ado, S. G. (2017). Agriculture: Panacea for Nigeria's Economic Recession. Invited Paper presented at the 22nd Amah Convention held at Sultan Muhammad Macedon Institute for Qur'an and General Studies, Soot, April 15-17, 2017, 30 pp.

Agbemava, E., Nyarko, I. K., Adade, T. C. \& Bediako, A. K. (2016). Logistic Regression Analysis Of Predictors Of Loan Defaults By Customers Of Non-Traditional Banks In Ghana. European Scientific Journal. Vol.12 (1), Pp 175-189.

Ajani, O. I. Y \& Tijani, G. A (2009). The role of Social Capital in Access to Micro Credit in Ekiti State, Nigeria, Pakistan Journal of Social Sciences vol 6(3), pg 125-132.

Armendariz de, A. B. \& Morduch, J. (2005). The Economics of Microfinance, Cambrdge MA: MIT press.

Guttman M. J. (2007). Repayment Performance in Microcredit Programs: Theory and Evidence, Working Paper-11, Networks Financial Institute, Indiana State University.

Kanu, I. M. (2020). Analysis of cocoa farmer's poverty status in Abia State, Nigeria: The Foster, Greer and Thorbeck (FGT) decomposable poverty measure. International Journal of Agriculture, Environment and Food Sciences, Vol. 4 (2), Page 188-199.

Kanu, I. M. \& Nwaru, J. C. (2020). Analysis of Resource Use Efficiency and Elasticity of Production among Smallholder Broiler Producers in Ikwuano Local Government Area of Abia State, Nigeria. International Journal of Agriculture, Environment and Food Sciences, Vol. 4 (4), Page 432-438.

Karlan, D. (2006). Social Connections and Group Banking. Economic Growth Center, Yale University New Haven, CT 06520.

Lawal, J. O, Omonona, B. T, Ajani, O. I. Y \& Oni, O. A (2009). Effects of Social Capital on Access to Credit among Cocoa Farming Households in Osun State, Nigeria, Agricultural Journal vol. 4 (4), pg 184-191.

Okezie C. R., Kanu I. M. \& Nwosu R. O. (2020). Effect of social capital on private adaptation measures to climate change among farmers in Ezinihitte Mbaise, Imo State, Nigeria. International Journal of Agriculture, Forestry and Life Sciences, Vol 4 (2): Page 303-310. 
Okezıe, C.R. \& Kanu, I. M. \& Iwu, C. C.( 2021). Social Capital and Loan Repayment Capacity of Agripreneurial Groups' in Abia State, Nigeria. BILTURK, The Journal of Economics and Related Studies, 3(3), 117-132. doi: 10.47103/bilturk.941862.

Oladeebo J. O. \& Oladeebo O. E.( 2008) Determinants of Loan Repayment among Smallholder Farmers in Ogbomoso Agricultural zone of Oyo State, Nigeria. Journal of Social Science, vol 17(1): pg 59-62.

Olomola, A. S. (2008). Social Capital, Microfinance Group Performance and Poverty Implications in Nigeria. Nigeria Institute of Social and Economic Research (NISER) Ibadan.

Uche, C. \& Familusi, L. C. (2018). The Adoption of Agripreneurship as a Mitigating Measure to Unemployment in Nigeria: A Topical Review. Global Journal of Management and Business Research. Volume 18 Issue 2 Version 1.0. Pp 24-31.

Yusuf, S. A. (2008). Social capital and households' welfare in Kwara State, Nigeria. Journal of Human Ecology, Vol. 23, pg 219-229. 